\title{
Blaze in Volga: Is it a critical point for the fall in Caspian Sea level?
}

Some areas of the northern hemisphere are experiencing very hot and dry weather this summer. Drought could affect very quickly enclosed and sensitive environments of Eurasia. The Caspian Sea, being a closed basin since the beginning of the Quaternary, has experienced important water fluctuations over its lifetime. Some of the historical sealevel oscillations have been mentioned in literature and occasionally preserved in coastal sediments. Caspian Sea level fluctuations with an amplitude of $3 \mathrm{~m}$ have been recorded since the end of $19^{\text {th }}$ century coinciding with instrumental measurement of the Caspian Sea level. The last sea-level rise began in 1979, stabilizing in a highstand period since 1995, in spite of minor oscillations. The main driver of sea-levels seems to be summer precipitation over the Volga drainage basin. Moreover, the La Niña phase of ENSO also correlates with drought over the Volga basin, which is the case this summer. In addition to natural processes, direct human impacts including massive dam construction across the Volga River after WWII, has influenced the Caspian Sea level to some degree. Water consumption in the Caspian catchment basin, mainly from the Volga, reduced the Caspian Sea level by an order of $1 \mathrm{~m}$.

The surface area of the Caspian catchment basin is around ten times greater than the
Caspian Sea surface itself. The latitudinal extension of the sea results in climate variations over the basin from sub-tropical in the southwest to desertic in the northeast. Riverine influx into the Caspian Sea and evaporation over the sea surface are the main factors influencing the Caspian water balance. This summer, the lowlands of the middle and upper Volga have been very dry due to the prevalence of dry weather from end of June to early August 2010. These high temperatures and drought are comparable to the historical record of late $19^{\text {th }}$ century that decreased Volga discharge and caused sealevel fall. Wildfire in the Volga basin is one of the first consequences of the hot and dry weather. It could impact social and natural environments in the Volga basin in different ways. The changes in the Volga catchment basin will be received with a time delay by the Caspian Sea. Decreasing the precipitation over the Volga basin will affect the input of the Volga River and consequently will change its water balance. Is it time for a sharp fall of the Caspian Sea level? The last drop occurred after 1995 and was followed by small sealevel ups and downs. However, the highstand has extended over the last three decades. During these past three decades, coastal communities have adapted themselves to a sea-level rise trend. Rapid construction of sea walls, transposition of residential areas and development of breakwaters are the main civil engineering works required to adapt to the sea-level rise. A sea-level fall may cause the Caspian coastal communities to be faced with new problems, such as exposing sea walls between residential areas and new beaches, inefficiency of the ports due to shallowing of the coastal waters and heightening of the port board. Sea-level fall affects marine and coastal ecosystems in another way, by accelerating the circulation of water masses. Therefore, nutrient exchange and oxygen flux will occur faster and consequently provide better conditions for biological productivity, and perhaps even eutrophication. However, some coastal lagoons will dry up and/or will be reduced due to the recession of the sea surface and the dropping of the groundwater table. The drought over the Volga drainage basin may therefore have wide ranging effects and impact communities from Russia to Iran.

Dr Hamid Lahijani, INCO, Tehran

Prof. Suzanne Leroy, Brunel University, UK

Majid Naderi Beni, INCO, Tehran

Dr Klaus Arpe, Max Plank, Germany and Brunel University, $U K$ 